\title{
Is it Necessary to Soak Rice Grains to Prepare Rhizoctonia solani AG-4 Inoculum?
}

\author{
Trazilbo J. Paula Júnior ${ }^{1}$, Rogério F. Vieira ${ }^{1}$, Waldir C. Jesus Junior ${ }^{2}$, Bernhard Hau ${ }^{3}$ \& Hudson Teixeira ${ }^{1}$ \\ ${ }^{1}$ Empresa de Pesquisa Agropecuária de Minas Gerais, Epamig, Vila Giannetti 47, CEP 36570-000 Viçosa, MG, Brazil, \\ e-mail: trazilbo@epamig.br; ${ }^{2}$ Universidade Federal do Espírito Santo, UFES, CEP 29500-000, Alegre, ES, Brazil; \\ ${ }^{3}$ Institute of Plant Diseases and Plant Protection, Leibniz Universität Hannover, 30419 Hannover, Germany
}

Author for correspondence: Trazilbo J. Paula Júnior

PAULA JÚNIOR, T.J., VIEIRA, R.F., JESUS JUNIOR, W.C., HAU, B. \& TEIXEIRA, H. Is it necessary to soak rice grains to prepare Rhizoctonia solani AG-4 inoculum? Fitopatologia Brasileira 32:501-503. 2007.

\begin{abstract}
A study was conducted to evaluate the effects on the development of root rot on common bean, cv. 'Dufrix' after treatment with four volumes of water $(0,30 \%, 60 \%$, and $90 \%, \mathrm{v} / \mathrm{w})$ added to rice grains previously immersed in water for 24 hours before autoclaving and colonization of grains by Rhizoctonia solani AG-4. Colonized rice grains and non-infested rice grains were mixed in pots with sterilized soil and sand (2:1), where beans were sown. Based on results of area under plant emergence curve, plant height, plant dry weight, and disease severity, we conclude that inoculum is more effective in causing disease when no water is added to the rice grains before autoclaving.

Additional keywords: Phaseolus vulgaris, soilborne pathogen, methodology, root rot.

\section{RESUMO}

É necessário embeber os grãos de arroz para o preparo de inóculo de Rhizoctonia solani AG-4?

Foi conduzido um estudo com o objetivo de avaliar os efeitos de quatro volumes de água $(0,30 \%, 60 \%$ e $90 \%$, v/p) adicionados a grãos de arroz previamente embebidos em água por 24 horas antes de eles serem autoclavados e colonizados por Rhizoctonia solani sobre o desenvolvimento da podridão-radicular de feijão, cv. 'Dufrix'. Grãos de arroz colonizados e não colonizados foram misturados em vasos contendo substrato de solo e areia (2:1), com posterior semeadura de feijão. Baseados nos resultados de área abaixo da curva de emergência das plantas, altura das plantas, massa de plantas secas e severidade da doença, conclui-se que o inóculo é mais eficiente em causar doença quando não se adiciona água aos grãos de arroz antes de eles serem autoclavados.
\end{abstract}

Palavras-chave adicionais: Phaseolus vulgaris, patógeno habitante do solo, metodologia, podridão-radicular.

Root rot caused by Rhizoctonia solani J.G. Kühn is a limiting factor in the commercial production of common beans in Latin America and Africa. Seed and seedling infections result in severe pre- and post-emergence dampingoff or root rots, which reduce plant stands (Abawi, 1994). Disease development is affected by several environmental and edaphic factors (Paula Júnior, 2002). Artificial inoculation of $R$. solani requires standard procedures that ensure comparable results. Different methods have been used in order to put $R$. solani propagules in contact with bean roots, including soil infestation with mycelial discs, sclerotia, and inoculum grown on cereal grains (Carling \& Sumner, 1992). The use of different methodologies to prepare $R$. solani inoculum on grains may lead to changes of the inoculum potential in the soil and to variable results. The purpose of the present study was to investigate the effects of four volumes of water added to rice grains on its colonization by $R$. solani and the development of root rot on common bean.

The study was conducted at the Institute of Plant Diseases and Plant Protection (IPP), University of Hannover, Germany. The isolate of $R$. solani (AG-4) from the fungi collection of the IPP was used. It was originally isolated from common bean plants and maintained at $4{ }^{\circ} \mathrm{C}$. This isolate was recovered and cultivated on plates with potatodextrose-agar at $25^{\circ} \mathrm{C}$.

Parboiled rice grains were kept immersed in water for 24 hours. Thereafter, they were washed and the excess water drained. Fifty grams of rice grains were placed in 200-mL Erlenmeyer flasks and four volumes of distilled water were added to the flasks: no water, $15 \mathrm{~mL}, 30 \mathrm{~mL}$, and $45 \mathrm{~mL}$. These volumes represented $0,30 \%, 60 \%$, and $90 \%$ of water volume by weight. Then the flasks were autoclaved at $120{ }^{\circ} \mathrm{C}$ for 20 minutes. Two 5-mm diameter mycelial-agar disks of $R$. solani were transferred from the margin of growing colonies to the flasks with rice grains. Grains were totally colonized by the fungus within six days of incubation in darkness at $25^{\circ} \mathrm{C}$. The colonized grains were dried in trays at room temperature for 24 hours.

Plastic pots with capacity of $1 \mathrm{~kg}$ were filled with 800 $\mathrm{g}$ of a mixture of sterilized soil and sand (2:1). This substrate was infested with $24 \mathrm{~g}$ of colonized rice grains. Non-infested rice grains, which were autoclaved after soaking in water for 24 hours and drained, were also mixed with the substrate (control treatment). Thus, the treatments were control plus four volumes of water $(0,15,30$, and $45 \mathrm{~mL})$ added to the rice grains before they had been autoclaved.

Ten seeds of the common bean cultivar 'Dufrix' 
were sown $3 \mathrm{~cm}$ deep in the pots, which were maintained under greenhouse conditions. Each pot was one replication. The experiment was repeated once. Both experiments were arranged in a randomized complete block design, with five replications. The percentage of emerged seedlings was daily assessed. The plants were removed from the pots 23 days after sowing (DAS), and hypocotyls were evaluated for disease severity according to a 1-9 scale, adapted from Van Schoonhoven \& Pastor-Corrales (1987): 1 - no visible symptom, 3 - light discoloration without necrotic lesions, $5-25 \%$ of the hypocotyl and root tissues covered with lesions but tissues remain, $7-25-50 \%$ of the hypocotyl and root tissues covered with lesions combined with softening, rotting, and reduction of the root system, $9-75 \%$ of the hypocotyl and root tissues affected with advanced stages of rotting combined with a severe reduction of the root system, or dead plants. Plant height and plant dry weight were also evaluated. The areas under plant emergence curve (AUPEC) were used for comparisons between seedlings' emergence rate. An analysis of variance (ANOVA) was performed on data, and Duncan's multiple range test (DMRT) $(P=$ 0.05 ) was used to compare the means of AUPEC.

As the results of both experiments were similar, just the results of the second experiment are shown. The presence of the fungus in the substrate delayed the seedlings' emergence one day (Figure 1) and fewer plants emerged, especially when no water was added to the rice grains. The AUPEC in this treatment was lower (171.7\%-days) compared to the higher volume of water mixed with the rice grains (241.7\%-days) and to the control treatment (520.0\%-days) (Figure 1). Plant height and plant dry weight increased and disease severity decreased with higher volume of water added to the rice grains (Figure 2).
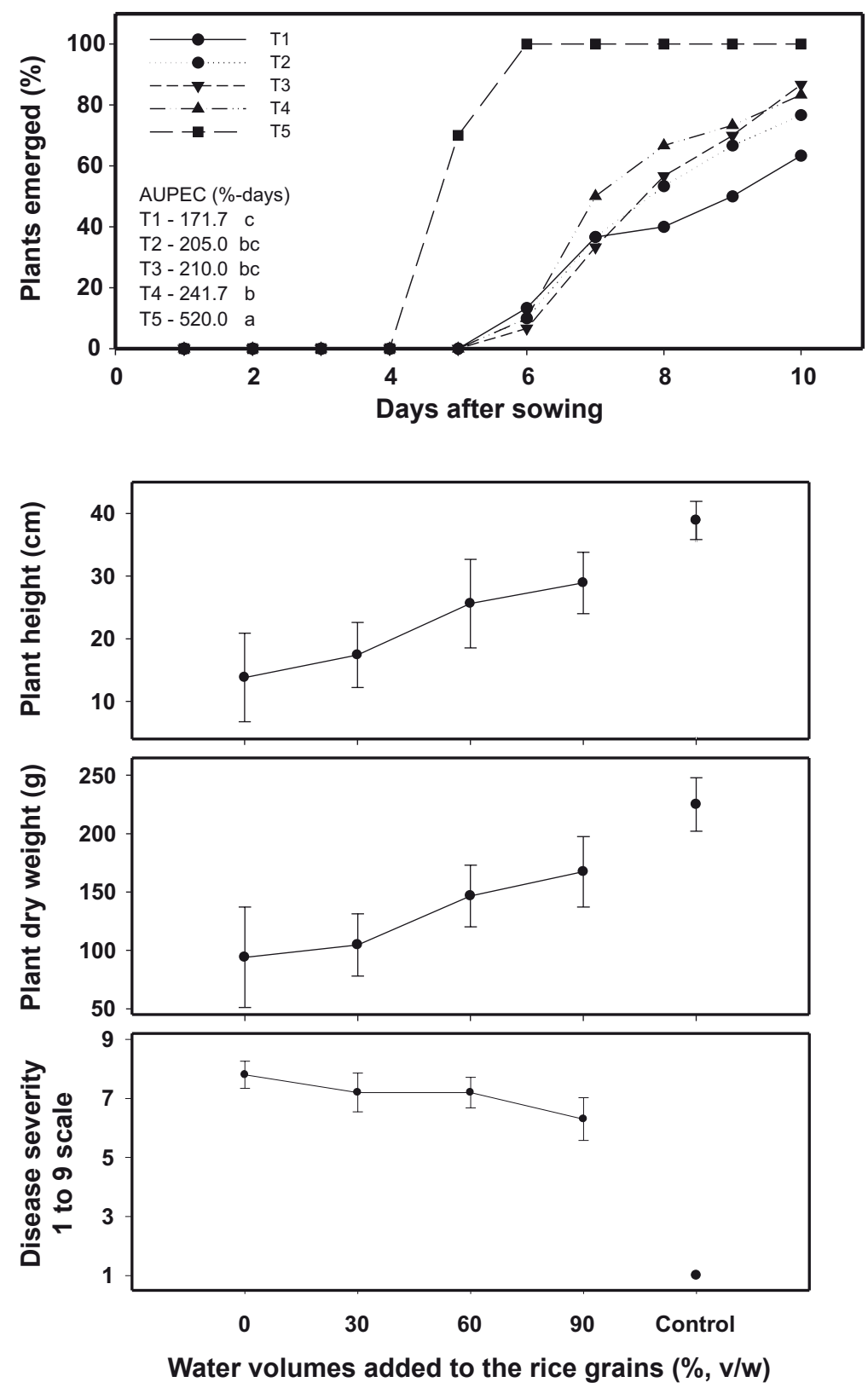

FIG. 1 - Effects of Rhizoctonia solani AG-4 on the area under plant emergence curve (AUPEC, \%days) in response to four volumes of water added to the rice grains $(\mathrm{T} 1=0, \mathrm{~T} 2=30 \%, \mathrm{~T} 3=60 \%$, and $\mathrm{T} 4$ $=90 \%, \mathrm{v} / \mathrm{w} ; \mathrm{T} 5=$ control non-infested) before they had been autoclaved and colonized by the fungus. Means of AUPEC followed by the same letter are not significantly different by DMRT $(P=0.05)$.

FIG. 2 - Effects of Rhizoctonia solani AG-4 on plant height, plant dry weight, and disease severity in response to four volumes of water added to the rice grains $(\mathrm{T} 1=0, \mathrm{~T} 2=30 \%, \mathrm{~T} 3=60 \%$, and $\mathrm{T} 4$ $=90 \%, \mathrm{v} / \mathrm{w} ; \mathrm{T} 5=$ control non-infested) before they had been autoclaved and colonized by the fungus. Vertical bars drawn through each point (mean of five replicates) represent the standard error of the mean. 
Rice grains have been frequently used for the preparation of $R$. solani inoculum (Michereff Filho et al., 1996; Silva et al., 1996; Paula Junior, 2002; Rodrigues et al., 2002). We conclude that the effectiveness of the $R$. solani in causing disease is higher when no water is added to the rice grains before they are autoclaved. The rice grains became swollen when water was added to them and, by cutting the grains, we observed that the fungus colonized just the surface. When no water was added to the rice grains, however, $R$. solani colonized both the outside and the inside of the grains. Therefore, the fungus is kept better protected in the soil and hence becomes more effective in colonizing bean roots. Thus, it is not necessary to soak rice grains to prepare $R$. solani AG-4 inoculum.

\section{ACKNOWLEDGEMENTS}

T.J. Paula Júnior and R.F. Vieira gratefully acknowledge grants offered by Conselho Nacional de Desenvolvimento Científico e Tecnológico - CNPq, H. Teixeira a grant offered by Fundação de Amparo à Pesquisa do Estado de Minas Gerais - FAPEMIG.

\section{REFERENCES}

ABAWI, G.S. Pudriciones radicales. In: Pastor-Corrales, M.A.
\& Schwartz, H.F. (Eds.) Problemas de Producción del Frijol en los Trópicos. Cali. CIAT. 1994. pp. 121-184.

CARLING, D.E. \& SUMNER, D.R. Rhizoctonia. In: Singleton, L.L., Mihail, J.D. \& Rush, C.M. (Eds.) Methods for research on soilborne phytopathogenic fungi. New York NY. APS Press. 1992. pp. 157-165.

MICHEREFF FILHO, M., MICHEREFF, S.J., SILVA, E.B., ANDRADE, D.E.G.T., ANTUNES SOBRINHO, S., NORONHA, M.A. \& MARIANO, R.L.R. Influência de tipos de solo do Estado de Pernambuco na intensidade da doença induzida por Rhizoctonia solani em feijoeiro. Fitopatologia Brasileira 21:19-25. 1996.

PAULA JÚNIOR, T.J. Integrated management of bean Rhizoctonia root rot. PhD Thesis. University of Hannover. Germany. 2002.

RODRIGUES, F.A., CARVALHO, E.M. \& VALE, F.X.R. Severidade da podridão-radicular de Rhizoctonia do feijoeiro influenciada pela calagem, e pelas fontes e doses de nitrogênio. Pesquisa Agropecuária Brasileira 37:1247-1252. 2002.

SILVA, J.B., MATOS, J.A.R., MICHEREFF, S.J. \& MARIANO, R.L.R. Efeito da bacterização de sementes no controle de Rhizoctonia solani em algodoeiro. Fitopatologia Brasileira 21:342-348. 1996.

VAN SCHOONHOVEN, A. \& PASTOR-CORRALES, M.A. Standard system for the evaluation of bean germplasm. Cali. CIAT. 1987. 